\title{
CONSTITUTIONAL REVIEW BY THE EXECUTIVE IN FOREIGN AFFAIRS AND WAR POWERS: A CONSEQUENCE OF RATIONAL CHOICE IN THE SEPARATION OF POWERS
}

\author{
JOHN O. MCGINNIs*
}

\section{INTRODUCTION}

In war powers and certain other areas of foreign affairs, the executive rather than the judiciary appears to exercise the constitutional authority to declare "what the law is." For instance, when presidents have committed troops to foreign hostilities in the past decade, they have claimed the constitutional authority to do so without congressional authorization, essentially refusing to acknowledge that they were bound by the War Powers Resolution. ${ }^{2}$ Recently, President Bush declared that certain provisions in two bills were not legally binding because they derogated from his authority in foreign affairs despite the fact that he himself had signed them into law. ${ }^{3}$ In each of these instances, the

Copyright $@ 1993$ by Law and Contemporary Problems

* Assistant Professor, Benjamin N. Cardozo School of Law.

From 1985-1987 I was an attorney-adviser and from 1987-1991 Deputy Assistant Attorney General in the Office of Legal Counsel, Department of Justice. I thus participated in drafting some of the materials discussed in this article.

I should also note that this article, except where otherwise indicated, is wholly descriptive rather than normative. It attempts to explain why the branches of government act as they do, not justify those actions, and does not necessarily endorse any of the doctrines and practices recounted herein.

My thanks to David Gray Carlson, Robert Delahunty, Neal Devins, Michael Herz, Arthur Jacobson, Douglas Kmiec, Mark Movsesian, Michael Paulsen, Michael Rappaport, Michel Rosenfeld, Paul Shupack, and Stewart Sterk for their comments.

1. Marbury v. Madison, 5 U.S. (1 Cranch) 137, 177 (1803) ("It is emphatically the province and duty of the judicial department to say what the law is.").

2. Two recent examples include President Reagan's military action in Grenada and President Bush's military action in Panama. See Letter to the Speaker of the House and the President Pro Tempore of the Senate on the Deployment of United States Forces in Grenada, PUB. PAPERS 1512, 1513 (Oct. 25, 1983) ("This deployment of United States Armed Forces is being undertaken pursuant to my constitutional authority with respect to the conduct of foreign relations and as Commander-in-Chief of the United States Armed Forces."); Letter to the Speaker of the House of Representatives and the President Pro Tempore of the Senate on United States Military Action in Panama, PUB. PAPERS 1734, 1734 (Dec. 21, 1989) ("The military operations were ordered pursuant to my constitutional authority with respect to the conduct of foreign relations and as Commander in Chief."). Both reports stated that they were being filed "consistent with" the War Powers Resolution, but did not acknowledge the constitutional force of the Resolution. For further discussion of the executive's strategy in dealing with the War Powers Resolution, see infra notes 116-29 and accompanying text.

3. For a discussion of these provisions, see infra notes 73-101 and accompanying text. As we shall see, such refusals to enforce provisions that relate to the president's foreign affairs prerogatives have not been limited to President Bush. 
Office of Legal Counsel ("OLC"), the central voice of executive branch legal interpretation, wrote an opinion as elaborate as a judicial opinion supporting the President's view that the provision at issue was unconstitutional. The President's apparent exercise of constitutional review in such cases is also highlighted by the judiciary's complementary tendency to avoid exercising substantive review over foreign policy or war powers disputes between the executive and legislative branches.

The executive's declaration of law in these areas may at first seem anomalous given the usual understanding of constitutional review as a judicial power. In my view, however, far from being anomalous, the executive's effective exercise of constitutional review in its primary areas of interest reveals an essential truth about the separation of powers as actually practiced: the relation of the branches to the governmental powers they exercise is fluid rather than fixed. A power often does not remain in the branch in which it was initially placed, but may instead effectively be exercised elsewhere on account of the implicit bargains and accommodations that reflect the interests and capacities of the branches. Because decisions about such matters as troop commitments and the conduct of negotiations are so much more central to executive interests than to those of the judiciary or Congress, the executive and judiciary have structured the constitutional regime to allow the executive itself the opportunity to shape the law in these areas. Thus, even the power of constitutional interpretation, the fundamental authority in a constitutional republic, is neither indivisible nor immovable, but may be disaggregated so as to allot a portion to the branch that will gain the most utility from its exercise.

This article proceeds in two parts. First, it offers a model of institutional rational choice to describe the actual practice of the separation of powers-a model in which governmental powers are often distributed by the branches themselves through bargains and accommodations that maximize their respective interests. Second, the article seeks to illuminate this model by examining the accommodation in the foreign policy and war powers area and the manner in which it reflects the balance of interests among the branches. Because this accommodation is derived from the interests of the branches rather than directly from the text of the Constitution, its legitimacy, like the legitimacy of any accommodation based on power, is always open to challenge or revision. This second part, therefore, also describes how the executive, acting through its constitutional lawyers, exercises its interpretative authority both to legitimize and entrench favorable accommodations and to trade its powers for other, highervalued, concessions. 
II

AN OUtline of the SEPARATION of Powers as a System of Rational CHOICE AMONG THE BRANCHES

\section{A. The Separation of Powers and the Exchange of Powers}

This section constructs a model of separation of powers jurisprudence on the basis of the institutional interests of the branches. While it does not purport to define the interests of each branch exhaustively, ${ }^{4}$ it is premised on the notion that the branches, like countries, have interests that will shape separation of powers doctrine. Of course, it is recognized that institutional interests are not in practice the only influence on separation of powers doctrine; ideological and personal interests surely play a role. ${ }^{5}$ Nevertheless, because ideological and personal interests are likely to be more fluctuating and evanescent, they are likely to have less influence in the long run than do institutional interests in shaping evolving norms. ${ }^{6}$ Indeed, given the centrality of institutional interests, organizations designed to protect these interests, such as OLC, naturally arise within the branches to counteract the effect of other interests. ${ }^{7}$ Accordingly, it seems useful to consider the explanatory power of a model premised on the idea that branches may shape separation of powers doctrine through bargains and accommodation to advance their mutual institutional interests.

The Constitution distributes governance among the three branches. Insofar as the rights of governance are analogous to the rights of private economic actors, we would expect the initial distribution of these rights to be merely a baseline for bargains from which the actors would seek to improve their initial positions. Both private and public actors can improve their utility by trading rights whenever the exchange leaves both actors with a set of rights from which they could enjoy greater utility than that afforded by the previous set. ${ }^{8}$ In so

4. For a fascinating attempt to present a detailed positive economic theory of judicial behavior which focuses on judges' institutional interests, see Richard A. Posner, What Do Judges and Justices Maximize (The Same Thing Everybody Else Does) (Working Paper March 15, 1993) (copy on file with author).

5. See Edward L. Rubin, Beyond Public Choice: Comprehensive Rationality in the Writing and Reading of Statutes, 66 N.Y.U. L. REV. 1, $32-35$ (1991) (discussing the ideological and interpersonal motivations of legislators).

6. Even institutional interests are not wholly constant because they may change as the public's perception of the institution changes. Thus, the contours of the bargains will not remain constant over time. In cooperative games, "strategies change over time as a function of their relative success in an ever-changing environment of other players who are also changing their own strategies with experience." Robert Axelrod, An Evolutionary Approach to Norms, 80 AM. POL. SCI. REV. 1095, 1110 (1986). The contours of the accommodation are always subject to renegotiation. For a discussion of an attempt to change the norms in the war powers area, see infra notes 109-110.

7. For a discussion of the manner in which the Office of Legal Counsel advances the institutional interests of the executive branch, see infra notes 102-05, 150 and accompanying text.

8. Institutional actors receive satisfaction from a variety of sources, including income, public esteem and prestige, and relative autonomy in decisionmaking. A theory that seeks to explain actions as a result of the maximization of the relevant actors' interests does not depend on the assumption that the parties are seeking money, but rather "on the assumption that no matter what people's objectives may be, they 
doing, actors move from the initial distribution of rights to a new equilibrium (the Pareto-optimal equilibrium) where no actor can further improve his position without diminishing the position of another actor. ${ }^{9}$ The possibility of such bargains is a consequence of the hypothesis that the branches are rational actors, each of which prefers to exercise the rights of governance that bring it prestige and to avoid exercising the rights of governance that may bring it harm. ${ }^{10}$

The analogy to bargains that take place in markets for private rights, however, is an imperfect one. First, in private markets there are central enforcement mechanisms for bargains; the absence of an enforcement mechanism can create very high transaction costs, thus inhibiting bargains. Indeed, because the rights at issue are the rights of governance, the potential bargainers are also the potential enforcers, thus ensuring that the system for enforcing rights is inevitably bound up with the distribution of the rights themselves. Second, instead of a market with a potentially infinite number of actors, in the separation of powers context there are a limited number of actors. ${ }^{11} \mathrm{~A}$ limitation on the

are rational in pursuit of them ... [and] will allocate their limited means among alternative pursuits to maximize their personal satisfaction." Michael E. Debow \& Dwight R. Lee, Understanding (and Misunderstanding) Public Choice: A Response to Farber and Frickey, 66 TeX. L. Rev. 993, 996 (1988).

While the model focuses on the utility of the rules to institutions, it is not radically different from a model of politics based on individual satisfactions. See JAMES BUCHANAN \& GORDON TULLOCK, THE CALCUlus of CONSENT: LOGICAl Foundations OF CONSTITUTIONAL DEMOCRACY 11-15 (1967). Individuals in office have a strong interest in the perquisites of their office, because it is through those perquisites that officials gain reputation and power. The confluence between the interests of the office and the person will be greater when the person expects to occupy the office for a long time, such as in the case of life-tenured judges.

9. Gregory Sidak has also seen the possibility of bargains between the branches. J. Gregory Sidak, To Declare War, 41 DUKE L.J. 27, 63 (1991) ("Regardless of the initial assignment of powers under the Constitution, and as long as transaction costs are not too high, the Coase theorem suggests that the three branches will be able to reassign those powers in any manner that achieves greater efficiency in the production of public goods." (footnote omitted)). Mr. Sidak's formulation seems to suggest that the branches will seek to maximize the efficient production of public goods rather than the utility of the branches themselves. While there may certainly be a relation between the branches' utility and the production of public goods, a theory of rational choice suggests that the branches will act in their own interests rather than in the interest of the public. Moreover, for reasons indicated below, I do not believe that all the preconditions for application of the Coase theorem are satisfied. For a description of the Coase theorem, see Ronald Coase, The Problem of Social Cost, 3 J.L. \& ECON. 1 (1960) (stating that private rights in the absence of transaction costs will ultimately be assigned to the actor who can make most productive use of the rights). Sidak also fails to appreciate that once a model of rational choice is applied to the separation of powers, the judiciary must be analyzed as one of the bargainers. See infra note 134 .

10. These rational choices may result in explicit bargains, as when the president permits Congress the right of legislative veto, see infra notes $141-50$ and accompanying text; in implicit bargains or accommodations, as the decision by the judiciary to give the initiative of constitutional interpretation to the executive in foreign affairs, see infra notes 68-70 and accompanying text; in unilateral actions by a branch to improve its enjoyment of the rights of the governance, as the judiciary's creation of the incorporation doctrine, see infra note 19; or in actions by one branch to discard a right of governance that it would prefer not to exercise, as the Congress's attempt to give back to the judiciary the responsibility for ensuring that laws properly accommodate religion, see infra notes $40-41$ and accompanying text.

11. Professor Koh argues that because institutions, such as Congress, have internal structures that do not follow simple market mechanisms, the Coase theorem is simply inapplicable to separation of powers analysis. See Harold Hongju Koh, The Coase Theorem and the War Powers: A Response, 41 DUKE L.J. 122, 129-30 (1991). It is certainly true that Congress has a variety of internal institutional 
number of actors may also inhibit the search for Pareto-optimality; it is well known that bargaining among bilateral monopolies introduces strategic considerations into bargaining that may well frustrate the movement toward an optimal state of distribution. ${ }^{12}$

The important distinctions between the rights of governance and private economic rights, however, do not deprive an implicit bargaining or accommodation model of all explanatory power in analyzing a system of separation of powers, because bargaining can take place even with a limited number of actors and absent a centralized enforcement mechanism. The bargaining under such limitations, however, is not assured of reaching a Pareto-optimal state. ${ }^{13}$ For instance, it has been shown that cooperative agreements can take place even in the absence of third-party enforcement mechanisms. ${ }^{14}$ Cooperation can occur in such circumstances because each party will deter the other from violating the agreement by the threat of future retaliation. ${ }^{15}$ In fact, we observe frequent communications between the legislative and executive branches over the use of the president's veto despite the fact that any formal agreement concerning the veto would clearly be unenforceable. ${ }^{16}$

As game theory also suggests, a bargaining or accommodation model may have explanatory power even when parties cannot make explicit agreements, as long as a party understands that another party has the capacity to reward and retaliate and that certain actions may lead to reward or retaliation. ${ }^{17}$ In the context of separation of powers, for instance, retaliation by the other branches

structures that are not market-oriented, such as committee systems, but the existence of non-market internal structures does not preclude bargaining. Indeed, many of the institutional structures such as the committee system in Congress and the bill clearance process in the executive facilitate bargaining between the branches. See infra note 16.

12. See Stewart Sterk, Neighbors in American Land Law, 87 ColUM. L. REV. 55, $57-58$ (1987) (noting that efficient results are not necessarily produced when parties have substantial market power).

13. Professor Koh is, therefore, correct when in criticizing Sidak, supra note 9, he suggests that the preconditions of the Coase theorem do not strictly apply to trading in the rights of governance under the separation of powers. See Koh, supra note 11, at 129-30.

14. See, e.g., Robert AXElrod, The Evolutrion of COOPERATION 73 (1984) (discussing emergence of tacit truces between opposing battle lines in World War I).

15. Indeed, in private law extra-legal sanctions, such as the threat of loss of future benefits from the contractual relation or the loss of a reputation for fair dealing, may play a very large role in policing opportunistic legal behavior. See Stewart Macaulay, An Empirical View of Contract, 1985 WIS. L. REV. 465,468 ("However, people engaged in business often find that they do not need contract planning and contract law because of relational sanctions."). Thus, even the market for private rights is ordered in part by decentralized enforcement mechanisms.

16. The bargaining model predicts that institutions would emerge over time to facilitate bargains between the branches. In fact, the president has created a centralized review process for deciding when the veto power will be used. The review process enables his administration to present a unified position on a bill which makes bargaining easier. See Richard E. Neustadt, Presidency and Legislation: The Growth of Central Clearance, 48 AM. POL. SCI. REV. 641, 668-71 (1954) (describing growth of centralized process for presidential review of legislation).

17. The notion of striking implicit bargains in the absence of direct communication is not unfamiliar to the law; many models of collusion in oligopolistic markets eschew reliance on communication between potential colluders. See Ian Ayres, How Cartels Punish: A Structural Theory of Self-Enforcing Collusion, 87 ColUM. L. REV. 295, 297 (1987). ("In game theory models of collusion, the term 'agreement' does not imply a formal communication-all that is needed is for the cartel members to have an 'understanding' of how others will react to their behavior."). 
against the Supreme Court can take a variety of forms: the legislature could restrict the Court's jurisdiction or impeach its Justices, and the executive could refuse to enforce a judgment of the Court. These actions would strike at the heart of the Court's authority. Even if the legislature is unlikely to take such action in a given case, the mere possibility of retaliation may act as a deterrent to rulings that would thereby jeopardize the Court's authority and political standing, thus facilitating successful future retaliation. ${ }^{18}$ Because of this interdependence, the Court would rationally take into account the interests of the other branches in shaping its doctrine to minimize friction while nevertheless advancing its own interests. ${ }^{9}$

Moreover, bargains may still be struck in markets where the limited number of actors leads to strategic considerations, although they may be different than those made under circumstances more closely approximating perfect competition. ${ }^{20}$ In a market dominated by a bilateral monopoly, private legal norms are often structured to allocate certain rights to the actor who values them most, thereby minimizing strategic bargaining. ${ }^{21} \quad$ Such a method of allocation helps explain why the judiciary may assign a right of governance, such as the right to commit troops to hostilities, to the branch that would value it the most: the judiciary can generally expect the greatest return for itself (or the least net

18. Thus, as I discuss below, the executive branch constantly emphasizes its responsibility for protecting the lives and property of U.S. citizens in foreign affairs, because a refusal to respect the Court's judgment would be the most politically palatable when predicated on the argument of saving citizens' lives. The rational judiciary would consider this possibility in ruling on issues related to the war powers area. See infra notes 119-22 and accompanying text.

19. This model of the separation of powers may offer at least a partial explanation for doctrines as varied as the incorporation doctrine and the doctrine of Chevron U.S.A., Inc. v. National Resources Defense Council, 467 U.S. 837 (1984), in which the Court held that it will defer to executive agencies' interpretations of agency statutes unless the statute expressly addresses and resolves the issue. The former doctrine allows the judiciary to elaborate the bill of rights, a prerogative central to its prestige, without direct confrontation with the other branches, which have greater powers of retaliation than the states. The model thus also helps explain the huge disparity in the number of instances the Court has invalidated state as opposed to federal legislation. The latter doctrine also allows the judiciary to reduce confrontation by permitting it to decline to review administrative interpretations unless directly contrary to the intent of Congress.

Another area where the separation of powers has been shaped by the institutional interests of the branches is the delegation doctrine. Congress has given away much of its lawmaking authority to the executive agencies, perhaps because it has found the role of critic of rules made by the executive more congenial than that of direct lawmaking. Because the executive has not resisted these vast delegations, the Court now routinely validates them despite substantial normative arguments that they improperly give the executive legislative powers. The model of separation of powers offered here would predict that the Court would not seriously try to fashion a doctrine that would restrain delegation, because enforcing questions of degree against Congress and the president in this area would cause friction between the Court and the other branches. $C f$. United States v. Mistretta, 488 U.S. 361, 416 (1989) (Scalia J., dissenting) ("[T]he limits of delegation must be fixed according to common sense and the inherent 'necessities' of government coordination, and since the factors bearing upon these necessities are both multifarious and ... highly political ... it is small wonder that we have almost never felt qualified to second-guess Congress regarding the permissible degree of policy judgment that can be left to those executing or applying the law....") (citation and quotation omitted).

20. For a graphic depiction of how a bargain between two monopolists differs from that between a buyer and seller who are both in competitive markets, see LOUIS KAPLOW \& PHILIP AREEDA, ANTITRUST ANALYSIS 223 (1988).

21. Sterk, supra note 12, at 103. 
hostility from the other branches) by allocating a right to the highest valuing user. ${ }^{22}$

\section{B. The Separation of Powers and the "State of Nature"}

The bargaining or accommodation model begins from the premise that each branch of the federal government has only a share of governmental power over citizens of the republic. ${ }^{23}$ Thus, while each branch exercises some governmental power over citizens and enjoys the relation of governor to governed, its relation to the other branches is of an entirely different order, one of "shared" governmental power. ${ }^{24}$ Each branch is both a potential ally and adversary of the others, and is thus involved in what Schelling describes as a "bargaining" or "mixed motive" game in which there is a mixture of mutual dependence and conflict, of partnership and competition. ${ }^{25}$ Without rules governing distribution of the rights of governance among the branches, a situation akin to a state of nature would exist among the governing actors. ${ }^{26}$ (Indeed, the Framers themselves compared the branches to entities in a state of nature. ${ }^{27}$ ) From that "state of nature," one would expect an order to arise through implicit bargaining in which each branch seeks the rights of governance most suitable given its comparative advantages and interests. ${ }^{28}$ In the pure "state of nature" model,

22. This explanation assumes that the judiciary perceives that the executive and legislature have roughly equal capacity to retaliate against actions that interfere with their interests and are likely to retaliate roughly in proportion to the degree of interference.

23. Throughout this article I discuss the interests of each branch as if it were essentially unitary. This is obviously a simplifying assumption. The Congress is made up of two houses whose interests may diverge as an institutional matter. The judiciary is made up of various courts whose interests may also diverge. (For a discussion of how the divergent interests of the District of Columbia Circuit and the Supreme Court may explain doctrinal difference between these two courts, see infra note 67). Although it may be that the executive should be normatively understood as unitary in the sense that the president should control the actions of all of the executive's officers, see Steven G. Calabresi \& Kevin H. Rhodes, The Structural Constitution: Unitary Executive, Plural Judiciary, 105 HARV. L. REv. 1155 (1992), in actuality, the various departments of the executive inevitably acquire institutional interests that diverge from those of the president. See Stuart E. Eizenstat, The State of the Modern Presidency; Can It Meet Our Expectations?, OCCASIONAL PAPER 26, at 10-11 (University of Chicago 1990). Nevertheless, the various units of each branch share a sufficient measure of common interests, as opposed to other branches, to make a model based on the simplified assumption of unity worth exploring. The model can be refined as the assumption of unity is relaxed.

24. See Richard E. Neustadt, Presidential Power 33 (1960) ("The constitutional convention created a government of separated institutions sharing powers.").

25. Thomas C. Schelling, The Strategy OF CONFLict 89 (1960).

26. Of course, the situation imagined here among the branches is not wholly parallel to the classical state of nature where there were, of course, no legal institutions. In the separation of powers model offered here, institutions exist whose interests will be defined by the traditions and expectations of the people. The analogy between the separation of powers and the state of nature lies in the similar absence of positive rules and a centralized enforcement mechanism for such rules.

27. At the convention, Elbridge Gerry, for instance, indicated that the branches might seek alliances with one another implicitly suggesting a comparison between the branches and nation states. 2 THE RECORDS OF THE FEDERAL CONVENTION OF 1787, at 78 (Max Farrand ed., 1966) (remarks of Elbridge Gerry). Governor Morris compared the branches to neighboring "farms." Id., at 79 (remarks of Governor Morris).

28. For a discussion of the manner in which cooperation can arise in a state of nature (that is, in a context where there is no central enforcement authority), see AXELROD, supra note 14, at 3-27, 145-69. 
these interests and advantages would be defined without reference to the constitutional text. Instead, they might be understood in terms of the people's expectations of the branches or traditions concerning the branches of government.

Insofar as the Constitution creates rules explicitly assigning powers to one branch or another, the process of deriving separation of powers rules may at first appear to have an initial distribution that the "state of nature" model lacks. ${ }^{29}$ Nevertheless, the existence of a text does not make inapposite the bargaining or accommodation model that would govern in the "state of nature." First, the Constitution does not expressly and clearly address many important issues of separation of powers. To take three salient examples: the power over foreign affairs, the power to remove officers of the United States, and the power of constitutional review itself are addressed, if at all, by implication only. ${ }^{30}$ At the very least, in these vast areas where rights of governance do not appear clearly assigned, the content of constitutional doctrine may themselves be explained in part by implicit bargaining and accommodation among the branches. ${ }^{31}$

Moreover, the bargaining model may even be important to explaining the manner of the judiciary's enforcement of provisions that appear to assign powers more clearly and explicitly to one branch or another. ${ }^{32}$ The textual nature of a provision is not a sufficient explanation for the judiciary's relative fidelity to text in this area, given its disregard for the text of other provisions which are of less central concern to the other branches. ${ }^{33}$ Relatively clear provisions in the

For a discussion of the ways of enforcing contracts in a state of nature, see Anthony Kronman, Contract Law and the State of Nature, 1 J. L. ECON. \& ORG. 1 (1985).

29. As discussed below, however, an explanation of why the textual provisions in the separation of powers model are generally enforced may itself depend on a model of rational choice because the judiciary does not invariably interpret constitutional provisions according to their text. See infra notes 32-34 and accompanying text.

30. A formalist might claim that the assignment of each right of governance can be derived from the structure and the text of the Constitution. Even assuming that this is so, some of these derivations are more complicated than others. The more complicated the derivation and the less clear the answer to a constitutional question the more opportunity there is for the interest of branches to distort the derivation. Because each branch may interpret the Constitution, their conflicting interests will lead to conflicting views on the assignments, see infra note 37 and accompanying text. These conflicts may then be resolved by the process of implicit bargaining and accommodation.

31. Of course, the Constitution's express assignments of power help define the comparative advantages and interests of the branches. These advantages and interests in turn motivate choices and bargains by making those unassigned rights more or less valuable to the different branches. For instance, the fact that the Constitution makes the president the commander in chief gives the executive branch interests and advantages which are highly relevant to what kind of accommodations are reached concerning powers in the general foreign policy arena.

32. Cf. James Q. Wilson, Does the Separation of Powers Still Work?, 86 PUB. INTEREST 36, 38 (1987) ("It is hard to find an area of constitutional law in which the Court has been as nonactivist as with respect to the separation of powers. The uncharitable may argue that the Court's faithfulness to text on this issue is necessary to empower it to be activist on other issues, for without strict adherence to the doctrine of separated powers the Court itself might not be able to assert the authority, nowhere mentioned in the Constitution, to declare acts of Congress unconstitutional.").

33. For a discussion of the manner in which the Court has eviscerated the Contracts Clause, see Douglas W. Kmiec \& John O. McGinnis, The Contract Clause: A Return to the Original Understanding, 14 HASTINGS CONST. L.Q. 525 (1987). For a discussion of the manner in which the Court has overenforced the establishment clause, see Michael W. McConnell, Coercion: The Lost Element of 
separation of powers area may be enforced because they are natural focal points of bargains. ${ }^{34}$ Unless the interests of the branches would suggest a very different equilibrium, the constitutional text distinguishes one distribution from the many other distributions that could be reached by bargaining. Additionally, the risks the judiciary faces for eviscerating a core separation of powers provision are often greater than those it faces for misinterpreting other provisions, because textual assignments of governmental authority are of greater concern to the other branches. ${ }^{35}$ Indeed, the judiciary's principal authority under the Constitution-that of judicial review-is premised on the notion that the judiciary has the capacity to interpret the text more impartially than the other branches. If it fails or is perceived to fail in performing this function, it will lose one of its principal advantages in the eyes of the other branches-its capacity to be an honest broker. Thus under the explanatory model offered in this analysis there may ultimately be no sharp theoretical distinction between powers that are clearly distributed by the text and those that are not, because the textual assignment of power is only relevant insofar as following the text serves the institutional interests of the branches. ${ }^{36}$

Another reason for suggesting that accommodation and bargaining will often be at the center of the separation of powers is that, notwithstanding the existence of a constitutional text, the branches themselves are responsible for enforcing the commands of the Constitution against one another. Constitutional principles could be derived without reference to strategic considerations only if they were imposed on the branches by a wholly exogenous source like the deity (or by a branch that could always count on support of the deity). In the Constitution, the powers relating to enforcement are divided among the branches, introducing uncertainty about enforcement and, thus, a role for strategic behavior in determining the contours of constitutional powers. For instance, the judiciary may render judgments, but it is left to the executive to enforce those judgments. Congress may also use its power over jurisdiction and its power of impeachment to reach decisions about the content of constitutional rules. ${ }^{37}$ For this reason, one of the central issues in the bargaining game will be the question of which

Establishment, 27 WM. \& MARY L. Rev. 933 (1986).

34. Cf. SCHELLING, supra note 25 , at 111 (discussing the importance of focal points in bargaining over qualitative principles).

35. By "core powers," I mean powers that are clearly and expressly granted to a branch by the Constitution. For the reasons discussed above, core powers are as a general matter relatively less subject to renegotiation.

36. Because of the judiciary's interest in following the text, the textual nature of power will count heavily in shaping the accommodation reached by the branches.

37. Because the judiciary is not absolutely certain that its decisions will be accepted by the other branches, it often functions like a mediator in a bargaining game between the legislature and the executive. Like mediators generally, it has an incentive structure of its own. See ScHELLING, supra note 25 , at 144 . One of the judiciary's greatest incentives is avoiding the possibility of executive refusal to enforce a judicial decision, because successful nonenforcement would be a great blow to the judiciary's prestige and authority. 
branch will have the initiative of defining the rules in a particular area, making the power of constitutional review itself a subject of implicit bargaining.

Finally, even after a substantive power is formally assigned to one branch by either text or practice, opportunities exist for the branches to concede effective use of the power to another branch in exchange for some other authority or in the service of some other interest. For instance, Chadha decreed that Congress could not enjoy the power of the legislative veto, but could only act through legislation. ${ }^{38}$ Yet, as discussed below, the President of the United States succeeded in enacting a program of military aid to an allied rebel force only by agreeing in writing to give committees of both houses an effective veto over the distribution of aid. ${ }^{39}$ Another interesting example is Congress's recent decision to give back to the Supreme Court by statute the responsibility for deciding whether laws sufficiently accommodate religion under the Free Exercise Clause. ${ }^{40}$ This right had been handed to Congress and state legislatures by the Court in Employment Division v. Smith. ${ }^{41}$

Moreover, even if one branch does not expressly give another branch a right of governance, it still may be in its interest to effectively discard a right. For instance, even if the Court were to suggest that the president had hierarchical power over a unitary executive, a president might eschew the political costs of unifying the executive in areas not essential to successful governance. Such a president is making a strategic move familiar to game theorists: delegating an embarrassing power of decision to free himself from threats and retaliation. ${ }^{42}$ In this case, the president frees himself from threats and retaliation by legislators or interest groups to those parts of his program which are more important to him or her than the issues before regulatory agencies. ${ }^{43}$

\section{The Implications of Decentralized Separation of Powers Ordering}

The model of institutional rational choice has systemic implications for understanding the separation of powers. First, the model suggests that in a system of separation of powers the structure of the government itself is ordered not by the centralized application of fixed legal norms, but through the evolution

38. INS v. Chadha, 462 U.S. 919 (1983). In my view, the rules on bicameralism and presentment are sufficiently clear in the text of the Constitution that the Court had a substantial interest in enforcing them as written. See supra notes 32-34 and accompanying text.

39. For a discussion of this incident, see infra notes 141-150 and accompanying text.

40. The Religious Freedom Restoration Act of 1993, Pub. L. No. 103-141, 107 Stat. 1488.

41. 494 U.S. $872(1990)$. Congress may actually prefer not to elaborate on these rights since such elaboration would distract them from legislation, such as spending legislation, that would more directly advance their members' interests.

42. For a discussion of this delegation strategy, see SCHELLING, supra note 25, at 142.

43. A president, thus, may find it in his interest to leave the impression that the agencies are more independent than the doctrines of the Supreme Court on independent agencies would suggest. For a discussion of the reasons that the president may enjoy substantial control over independent agencies under current Supreme Court doctrine, see John O. McGinnis, Models of the Opinion Function of the Attorney General: A Normative, Descriptive and Historical Prolegomenon, 15 CARDOzo L. REV. 375 , 433 \& n. 217 (1993). 
of norms that reflect mutually advantageous arrangements among the branches. The governmental order that arises in our system of separation of powers paradoxically has much in common with the more spontaneous order that may arise where individuals work out mutually advantageous arrangements without the aid of a central coordinator. ${ }^{44}$ Viewed from this perspective, the Framers' solution to the danger of tyranny posed by the prospect of Hobbesian legal centralism was to create in some measure a state of nature at the heart of Leviathan. $^{45}$

Whether this solution makes it likely that the separation of powers will directly protect individual rights as a general matter is, however, open to doubt. $^{46}$ It is the institutions that are the actors in the bargaining game and, thus, it is the utility of institutions, not the rights of people that will directly be maximized by the accommodations. For instance, there is little doubt that the Framers gave the veto power to the president in part to enable him to veto unconstitutional laws, ${ }^{47}$ but the bargaining model suggests that he may bargain away this right in the interest of his office. ${ }^{48}$ Of course, given that some of the branches' interests are defined by the expectations of the people, there may not be a complete dichotomy between the interests of the branches and those of the people.

Another corollary of viewing the separation of powers as a system of bargains is to soften, if not dissolve, the antinomy between the functionalist and formalist views of the separation of powers. The formalist view holds that, in the absence of an express constitutional provision to the contrary, the executive, legislative, and judicial branches should be confined to the exercise of their

44. For a discussion of the manner in which such order can be created, see AXELROD, supra note 14, at 73-105; ROBERT C. ElliCKSON, ORDER WITHOUT LAW 230-64 (1991).

45. For a discussion of legal centralism, see ELLICKSON, supra note 44, at 138-40. Professor Ellickson contrasts the order that arises from the enforcement mechanism of central coordinator with the more spontaneous order that can arise in its absence. He argues that the legal centrist tradition has neglected consideration of decentralized forms of order which explain much social behavior. This article is in keeping with Ellickson's project because it is an attempt to show that in modern legal systems the very instrument at the center of legal centralism-the government itself-may be in large measure constituted by a more decentralized form of order.

46. It is similarly open to doubt that the separation of powers could successfully limit the general growth of governmental power, so long as all the branches were able to derive advantages from that growth. Cf. Geoffrey P. Miller, Independent Agencies, 1966 SUP. CT. REV. 41, 56 (observing that separation of powers has not limited the general "increase in the powers of all branches of the federal government").

47. See James Madison, Observations on Jefferson's Draft of a Constitution for Virginia, in 11 THE PAPERS OF JAMES MADISON 285, 292-93 (William T. Hutchinson ed., 1977).

48. The tension between the bargaining game that takes place in the separation of powers and public perception that separation of powers protects individual rights directly may in fact encourage tacit rather than explicit bargaining, even when explicit bargaining is possible, because too clear an articulation of the bargain might arouse the public by suggesting that the separation of powers does not protect individual rights. $C f$. SCHELLING, supra note 25, at 101 ("Illicit bargaining, or diplomatic bargaining that would be embarrassing to both sides if overheard ... may be less than fully articulate."). Therefore, it is not surprising that the Court does not make these considerations explicit in its decisions. 
respective powers. ${ }^{49}$ At its most expansive point, the functionalist view holds that the express categories of legislative, executive, and judicial are less important as long as the branches come to institutional accommodations that are well designed to address pressing governmental and political problems within a generalized framework of checks and balances. ${ }^{50}$ Understanding the pervasiveness of bargains and accommodations in separation of powers practice considerably softens the sharp dichotomy between formalist and functionalist models. Even when the rights of governance may be appropriately derived in the formalist manner, they will nevertheless be deployed pragmatically as the branches strike both explicit and implicit bargains among themselves.

Viewing the separation of powers as a system of bargains also has substantial implications for analyzing the effect of the Court's separation of powers decisions. Because each branch has very substantial powers that are not seriously contested as a matter of doctrine, any shift in the assignment of some of the rights of governance can only be understood and measured against the whole distribution of rights available for bargaining. For instance, despite the Court's holding that the Constitution deprived Congress of the right of legislative veto ${ }^{51}$ Congress continues to pass bills with legislative vetoes precisely to signal to the executive that in particular areas Congress or its relevant committees will use its core powers, such as the power of the purse, to require the executive to act as if a legislative veto were still in place..$^{52}$ If the executive and legislative branches may trade the rights of governance to their mutual advantage, the effect of a single separation of powers decision is not necessarily to be measured by the degree to which the specific rights of governance are formally reassigned, but by the degree to which the decision will change the overall equilibrium of bargains between the branches or the degree to which the decision will facilitate or impede these bargains.

While the model of separations offered here seems rich in explanatory power, I do not assert that it offers a complete explanation of all separation of powers decisions and actions of the branches. Fidelity to text, original understanding of a provision, or some other interpretative theory or political ideal may operate to restrict the influence of rational institutional self-interest. However, if

49. For a discussion of the formalist (Miller uses the term "neoclassical") view, see Miller, supra note 46 , at 53 .

50. For a discussion of the functionalist (Miller uses the term "pragmatic") view, see id. at 52. The formalist attack on the functionalist view is that its lack of well-defined boundaries will over the long run permit the constitutional system of separated powers to be distorted out of all recognition, probably to the advantage of Congress, given the legislature's ability to function as an "impetuous vortex" drawing all matters to itself. THE FEDERALIST No. 48, at 309 (James Madison) (Clinton Rossiter ed., 1961). The pragmatic attack on the formalist view is that its rigidity will greatly circumscribe the branches' ability to devise new systems of checks and balances against kinds of governmental powers such as the modern administrative agencies that the Framers could never have envisioned.

51. INS v. Chadha, 462 U.S. 919 (1983).

52. For evidence that Congress is passing legislative vetoes even seven years after Chadha, see Statement on Signing the Department of the Interior and Related Agencies Appropriation Act, 1991, PUB. PAPERS 1558, 1559 (Nov. 5, 1990) (observing that legislation contains numerous unconstitutional legislative veto devices). 
Schumpeter was correct in his claim that a society founded on capitalism and science tends to erode the various fidelities that restrain rational self-interest, we can expect institutional rational choice to become an ever more dominant explanation of separation of powers doctrine and practice..$^{53}$

\section{III}

\section{A Case Study in the Theory: Maintaining THE ACCOMmodation IN FOREIGN AFFAIRS AND WAR POWERS}

Foreign affairs and war powers are areas of the Constitution where the bargaining or accommodation model has particular relevance. While the text of the Constitution does assign specific foreign policy and war powers to the president (for instance, the authority to receive ambassadors ${ }^{54}$ and the role of commander-in-chief ${ }^{55}$ ) and to the Congress (for instance, the power to declare $w r^{56}$ and the power to raise and support armies ${ }^{57}$ ) it does not exhaustively enumerate all powers in these areas. In addition, the contours even of those powers enumerated are not clearly delineated. Therefore, the rights of governance in foreign affairs and war would appear to be prime candidates for assignment according to the implicit bargaining model.

The output under the model depends on the relative interests and aptitudes of the institutions that will bargain with and accommodate each other. ${ }^{58}$ These are partly defined by the textual provisions whose core is less likely to be disputed. $^{59}$ The president's power as commander-in-chief is relevant to his interests both because this gives him some power of initiative of action in war powers and because it creates the expectation that the president is immediately responsible for protecting the security of the nation and the safety of its citizens. $^{60}$ Given these expectations, the president will want to acquire the rights of governance over areas, such as diplomacy, which imminently affect the exercise of this responsibility. Additionally, the structure of the presidency as a single office possessed by one person also gives the executive unique capabilities of acting with "secrecy and dispatch," giving him a comparative advantage in

53. For a discussion of the way in which the rational calculation typified by capitalism naturally tends to eviscerate other values, see JOSEPH A. SCHUMPETER, CAPITALISM, SOCIALISM, AND DEMOCRACY 123-24 (1976).

54. U.S. CONST. art. II, \& 3.

55. Id. at art. II, $\$ 2$, cl. 1 .

56. Id. at art. I, $\& 8, \mathrm{cl} .11$.

57. Id. at art. I, $\$ 8, \mathrm{cl} .12$.

58. Here the interests are defined fairly roughly and intuitively. As a fuller theory of interests motivating the branches is developed, a more refined bargaining model can be applied.

59. For reasons that the best explanation that these core power are distributed according to text within a rational choice theory, see supra notes 32-34 and accompanying text.

60. Even adherents of greater congressional power in the war powers area recognize that the executive inevitably takes account of the "pervasive national perception that the presidency must act swiftly and secretly to respond to fast-moving international events." HAROLD HONGJU KOH, THE NATIONAL SECURITY CONSTTTUTION 122 (1990).

61. The Federalist No. 64 at 392-93 (John Jay) (Clinton Rossiter ed., 1961). 
carrying out these functions. Thus, because of the president's constitutional powers and because of expectations that have developed about his responsibilities in the area of foreign affairs and war powers, the president generally places a very high value on control of the rights of governance in foreign affairs. ${ }^{62}$

On the other hand, Congress's structure is so much more diffuse than the executive that it impedes the rapid decisionmaking necessary in the fluctuating world of foreign affairs. ${ }^{63}$ Thus, because of its comparative disadvantage as an institution, operational control of foreign affairs may actually be at odds with its interests because such control threatens Congress with responsibilities it is not well-equipped to handle. In determining how much interest Congress has in exercising this power as compared to the executive, one must compare this interest to other rights of governance. Spending on constituents, for example, is more highly prized by Congress since it can directly help individual members of Congress retain office. ${ }^{64}$ Of course, even if Congress rationally shuns operational control of war and foreign policy matters, it may be interested in increasing its mechanisms to criticize the executive's performance after the fact, so that it can act in effect as the ululating Greek chorus that comments on the executive's tragic choices. ${ }^{65}$

The Court has the least interest of all in exercising rights of governance in the foreign affairs and war powers areas. The Court does not have the institutional capacity to make assessments in these areas. Any inept decision about war and peace may have dramatic and readily understood real world consequences that may erode the Court's prestige and endanger its public respect. Thus, decisions in this area stand in contrast with decisions elaborating individual rights, a role in which it may appear as the tribune of the people. ${ }^{66}$

62. For reasons discussed above at notes $32-36$ and accompanying text, it is likely that some core powers will be so plainly conferred on one branch or another that they are not likely to be relocated. Moreover, if powers have been exercised by a particular branch over a period of time, expectations will develop concerning the exercise of that power that will themselves help determine the institutional interests of a branch.

63. Statement of Senator John Tower ("Congress is not structured to maintain the day-to-day business of the conduct of diplomacy. Congress is not structured to devise and maintain a long-term comprehensive, reliable foreign policy".), quoted in Statement of Abraham D. Sofaer, Testimony before the Senate Foreign Relations Committee reprinted as The War Powers Resolution, Current Policy 1107 at 3-4 (State Department 1988). For a discussion of the institutional difficulties of congressional control of national security issues, see KoH, supra note 60, at 123-26, 131-33. Although Professor Koh believes that the institutional problems can be addressed by Congress itself, see id. at 167-81 (suggesting institutional reforms), the fact that such reforms have never been enacted suggests that Congress does not perceive them to be in its interest, even assuming that they would be effective.

64. It is important to remember that comparative advantage is the touchstone of mutual accommodation: "[T]he things a player concedes should be those that he wants less than the other player, relative to the things he trades for." SCHELLING, supra note 25, at 117 . Comparative advantage is also relevant because, like any institution, Congress has limits in resources and time on the subjects it can address. For a discussion of the manner in which spending on constituents can help members of Congress retain office, see JOHN A. FEREJOHN, PORK BARREL POLITICs 47-68 (1974).

65. This interest may explain the existence of the War Powers Resolution. For further discussion of the Resolution see notes 109-40 and accompanying text.

66. The importance of the elaboration of individual rights to the Court can be gauged by the Court's vigorous reaction to challenges to its elaboration. For instance, in Cooper v. Aaron, 358 U.S. 
The latter decisions, even when controversial, are likely to have some group of supporters, and their real world consequences are less immediate and dramatic than issues of war and peace. Resistance, if encountered, can be tempered by incremental implementation. ${ }^{67}$

A useful thought experiment to aid in evaluating the interests of the Court in deciding war powers and other separation of powers cases is to imagine the Court divided into two entirely separate courts: a structural court and a rights court. The structural court would adjudicate only separation of powers and federalism, the structural provisions of the Constitution. The rights court would adjudicate only individual rights, principally the Bill of Rights. A structural court in such a regime may be rationally more interested in deciding more structural cases, because structural cases will be its raison d'être. ${ }^{68}$ A court, like the Supreme Court, with a discretionary jurisdiction that includes both rights and structural functions, however, would rationally consider the possibility that some structural cases would so endanger its political capital that they should be shunned.

Against this background of interests, it is therefore not surprising that the Court has largely ceded the rights of governance in foreign affairs and war powers to the executive, because the executive values them more. In this way, the Court maximizes utility among the branches and, thus, minimizes the chance of retaliation against its own interests. ${ }^{69}$ The Court, however, has largely given

1 (1958), the Court contended that any challenges to its civil rights jurisprudence were themselves an affront to the Constitution, because the decisions of the Court became part of the Constitution. In Planned Parenthood v. Casey, 112 S. Ct. 2791 (1992), the plurality attempted to insulate the right to abortion from further criticism by implicitly criticizing the executive branch for continuing to argue against it, $i d$. at 2803 , and by comparing the importance of adhering to the right to the importance of adhering to Brown v. Board of Education, 349 U.S. 294 (1955), Casey, 112 S. Ct. at 2815, a case to which adherence has become a sine qua non of confirmation for federal judges. The Court thus sent an emphatic message that the elaboration of constitutional rights is the Court's core power; if other branches attempt to "interfere" with this authority, it will even attempt to block that interference by structuring its opinions in a manner that will affect the confirmation process for Supreme Court Justices. I am indebted to Robert Delahunty and Nelson Lund for useful discussion on these points.

67. Brown is the classic example of "deliberate" implementation. The plurality opinion in the recent abortion case, Casey, also shows the way the Court may modify the contours of a decision in order to protect its authority to govern an area of civic life.

68. As I discuss below, we do have a court that is more predominantly structural in its docket-the District of Columbia Circuit. That court, in fact, appears to be decidedly more receptive than the Supreme Court to justiciability doctrines permitting more decisions on the merits in separation of powers cases. The District of Columbia Circuit has also favored far more searching reviews of administrative interpretations and the administrative process, where the Supreme Court has unanimously overturned such decisions, preferring more lenient standards of process and review that will cause less friction with the executive. See, e.g., Chevron U.S.A., Inc. v. Natural Resources Defense Council, 467 U.S. 837 (1984); Vermont Yankee Nuclear Power Co. v. Natural Resources Defense Council, 435 U.S. 519 (1978); see also Richard J. Pierce, Jr., Two Problems in Administrative Law: Political Polarity on the District of Columbia Circuit and Judicial Deterrence of Agency Rulemaking, 1988 DUKE L.J. 300, 306 (although the "D.C. Circuit is divided between political liberals and political conservatives the court's basic ideology [in administrative law] remains one of judicial activism [resulting in an] ideological incompatibility of the D.C. Circuit and the Supreme Court").

69. An example of retaliation would be the executive's refusal to obey an injunction of the Court ordering it to cease military activities. Given that the Court's essential authority depends on the voluntary compliance of the executive with its orders, such a refusal would strike at the heart of the 
this control to the executive not so much through substantive decisions favoring the executive (although there have been some substantive doctrines favorable to the executive), but through decisions invoking the political question doctrine or justiciability doctrine, thus providing the executive with some initial authority to fashion the substantive law in the area. ${ }^{70}$ The strategy of ceding power to the executive through decisions on such threshold matters rather than on the merits has three additional advantages for the judiciary. First, it provides the judiciary with a graceful way of avoiding substantive decisions against congressional interests. Second, since the Court has not put its imprimatur on a substantive allocation of rights in this area, Congress may more readily use its own powers to take concrete action against the executive, thus providing the judiciary with additional information about the value it attached to these rights. Given such information, the Court might find ways of redistributing some rights from the executive to the Congress without disturbing as much substantive precedent. ${ }^{71}$

Such congressional challenges to an accommodation between the executive and judiciary come in essentially two forms. Important public events may change the public assessment of the branches' capabilities and consequently Congress's own assessment of its interests. Less dramatically, Congress may simply wish to test the resiliency of the accommodation to see if it can acquire more power. As we shall see in the discussions below, both kinds of incidents are important to the bargaining game, because the moves of the branches in these games provide information to one another about their actual preferences and advantages, thus providing evidence on whether the accommodation previously reached is still appropriate in light of current interests. ${ }^{72}$ They also provide the executive branch with the opportunity to respond to such challenges by underscoring to the judiciary and Congress the balance of interests that led to the accommodation in the first place. ${ }^{73}$

Court's institutional interests. In a time of crisis, the executive has previously disregarded a court judgment. See Michael S. Paulsen, The Merryman Power and the Dilemma of Autonomous Executive Branch Interpretation, 15 CARDOZO L. REV. 81, 88-99 (1993).

70. See, e.g, Goldwater v. Carter, 444 U.S. 996 (1979). For a general discussion of this phenomenon, see KoH, supra note 60 , at $134-53$.

71. The Court might have to disturb its precedent on justiciability, but justiciability doctrines are notoriously elastic. See Mark Tushnet, The Sociology of Article III: A Response to Professor Brilmayer, 93 HARV. L. REV. 1698, 1705-1706 (1980). Moreover, disturbing substantive precedent may damage the Court's public reputation more than disturbing precedent on jurisdictional matters, because substantive precedent is more readily comprehensible to the public.

72. For a discussion of the information value of moves, see SCHELLING, supra note 25, at 115-17 ("[T]alk is not a substitute for moves. Moves can in some way alter the game, by incurring manifest costs, risks, or a reduced range of subsequent choice; they have an information content, evidence content, of a different character from that of speech. Talk can be cheap when moves are not ...."). Moves in this case consist of real world actions taken by the executive, legislative, and judicial branches, such as the enactment of legislation, the veto or refusal to enforce legislation, the commitment of troops, and judicial decisions.

73. In analyzing the executive branch's action as a strategy to maintain the accommodation in this area, I am not necessarily claiming that is it consciously calculated in all respects, just as I am not claiming that the judicial doctrines that play a part in the accommodation are consciously calculated: "Rational choice ... does not mean self-consciously economic choice, or even conscious choice. Economics does not seek to depict states of mind; it is concerned with what people ... do, not what they 


\section{A. The Executive's Rebuff of An Adventitious Congressional Challenge to the Accommodation}

One year into President Bush's term, Congress passed the Foreign Relations Authorization Act. ${ }^{74}$ The Act included a provision prohibiting the United States from spending any money authorized for international conferences on the U.S. delegation to the Conference on Security and Cooperation in Europe unless that delegation included representatives of the Commission on Security and Cooperation in Europe. ${ }^{75}$ This Commission was composed almost entirely of members appointed by the legislative branch. ${ }^{76}$

The reasons for Congress's decision to include this provision are obscure, ${ }^{77}$ but a former member of the National Security Council staff recalls that the Counsel to the Foreign Relations Committee of the House of Representatives was particularly interested in these negotiations and wanted to participate in them. ${ }^{78}$ The inclusion of the provision was a sharp challenge to the President's asserted powers in foreign affairs for two reasons. First, presidents from both parties have asserted their authority to represent the United States in foreign affairs and thus control the identity of U.S. negotiators. ${ }^{79}$ Moreover, presidents have also consistently claimed the absolute right to control national security information and prevent its disclosure to Congress-a power that would obviously be impaired if a representative of the legislative branch were required on the negotiating team. ${ }^{80}$

Given the far-reaching challenge to powers of the presidency, President Bush's response was extremely forceful. He announced that the provision was unconstitutional, and that he would refuse to enforce it, permitting him to

feel or think." Richard A. Posner, The Ethical Significance of Free Choice: A Reply to Professor West, 99 HARv. L. REv. 1431, 1439 (1986) (footnote omitted). Posner applies his observation to both market and nonmarket behavior.

74. Pub. L. No. 101-246, 104 Stat. 15 (1990).

75. Section 102(c)(1) of Pub. L. No. 101-246 (1990) authorized funds for "International Conferences and Contingencies." Section 102 (c)(2) stated:

None of the funds authorized to be appropriated under paragraph (1), may be obligated or expended for any United States delegation to any meeting of the Conference on Security and Cooperation in Europe (CSCE) or meetings within the framework of the CSCE unless the United States delegation to any such meeting includes individuals representing the Commission on Security and Cooperation in Europe.

Foreign Relation Authorization Act $\S 102(c)(2)$.

76. The Commission consisted of twenty-one members of Congress, eighteen of whom are drawn from the houses of Congress, three of whom are appointed by the President. 22 U.S.C. $\$ 3003$ (a) (1988).

77. Members of Congress justified the provision by complaining that the State Department had blocked representatives of the Commission from participating in the negotiations. See, e.g., 135 CoNG. REC. S8025-26 (daily ed. July 17, 1989) (statement of Sen. Fowler).

78. Telephone Interview with Steven Rademaker, then Deputy Legal Adviser to the National Security Council (Mar. 8, 1993) [hereinafter Rademaker Interview].

79. For an assertion of this right by President Carter, see infra note 94 and accompanying text.

80. The Office of Legal Counsel ("OLC") has collected many examples of executive refusals to provide national security information to Congress. See Memorandum for the Attomey General from Theodore B. Olson, Office of Legal Counsel, 6 Op. Off. Legal Counsel 751 (1982). The Court has supported the view that executive privilege in this area may be absolute. United States v. Nixon, 418 U.S. 683 (1974). 
continue spending funds on the conference. ${ }^{81}$ Announcing his refusal to enforce the provision served the purpose of protecting the boundaries of his powers better than vetoing the bill would have done. By claiming this right of refusal, the President was asserting a power of constitutional review over legislation that interfered with his constitutional prerogatives, at least in the area of foreign affairs. A veto, even if sustained, would not have permitted the President dramatically to assert a lawmaking role rivaling that of the Court in this area. ${ }^{82}$

The President's move effectively gave him the last word on the issue. ${ }^{83}$ Congress could have used its power of impeachment to assert its view of the Constitution (both as to the substance of the President's foreign affairs authorities and as to his authority to refuse to enforce a law), but its use of this power under these circumstances would have seemed politically implausible because of both the relative unimportance of the issue in the public's perception and the general level of support the President enjoyed among the public and Congress at the time. By refusing to enforce the law, the President had effectively called Congress's bluff, both raising the stakes and leaving Congress with no feasible way to make its law binding through the use of its own political powers.

81. In his signing statement the President stated:

Section 102 of the Act would prohibit the use of certain appropriated funds for any U.S delegation to any meeting within the framework of the Conference on Security and Cooperation in Europe unless individuals representing the Commission on Security and Cooperation in Europe, a body controlled by the legislative branch, are included in the U.S. delegation. By purporting to deny certain funds for the negotiation of certain arms control agreements unless representatives of the Commission are included in the U.S. delegation to such negotiations, this section impermissibly intrudes upon my constitutional authority to conduct our foreign relations and to appoint our Nation's envoys. I therefore shall construe it to express the sense of Congress but not to impose any binding legal obligation, and as severable from the ability to continue the critically important negotiations at issue.

Statement on signing the Foreign Relations Authorization Act, Fiscal Years 1990 and 1991, 26 PUB. PAPERS 266, 267 (Feb. 16, 1990). Although the President phrased his refusal diplomatically, saying he would treat the provision as advisory, his action was widely understood as a refusal to enforce because of the clearly mandatory nature of section 102 . Representatives of the CSCE were never included in the delegation. See Rademaker Interview, supra note 78. The Counsel to the Clerk of the House viewed the President's action as a refusal to enforce. See infra note 87.

82. President Bush seized a similar opportunity when Congress placed a condition on the State Department's appropriation that would have prohibited the issuance of more than one official passport to U.S. governmental officials. See Foreign Relations Authorization Act, Fiscal Years 1992 and 1993, Pub. L. No. 102-138, \& 219(e), 105 Stat. 647, 662 (1992); see also Statement by President George Bush Upon Signing H.R. 1415, statement on signing the Foreign Relations Auth. Act, Fiscal Years 1992 and 1993, PUB. PAPERS 1344 (Oct. 28, 1991) (suggesting that this provision intruded into his authority to conduct diplomacy). The law arose from a concern that the United States was issuing more than one passport to a single diplomat in order to comply with "the passport and visa policy of the majority of Arab League nations." H.R. CoNF. REP. No. 238, 102d Cong., 1st Sess. 107 (1991). The OLC rendered an opinion declaring that (1) the provision was unconstitutional, because it interfered with the president's authority in foreign affairs; (2) the provision was severable from the appropriation; and (3) the president had the authority to refuse to enforce this provision. See Memorandum to C. Boyden Gray, Counsel to the President, from Timothy P. Flanigan, Acting Assistant Attorney General, re: Issues Raised by Section 129 of Pub. L. No. 102-138 and section 503 of Pub. L. No. 102-140, 16 Op. Off. Legal Counsel 18 (1992).

83. For a discussion of moves by which one party "relinquish[es] [the] initiative, having rigged the incentives so that the other party must choose in [his] favor," see SCHELLING, supra note 25, at 37. 
Congress might also have attempted to challenge the President's lawmaking by invoking the judiciary's help, but this route was blocked by the regime that the judiciary had constructed to protect its interests and the interests of the executive. ${ }^{84}$ Any suit would have encountered serious justiciability issues. First, since the members were part of a legislative commission, it is unclear whether they could have asserted any interest beyond that of Congress itself. This may have raised a justiciability hurdle because the Supreme Court has not held that the interests of members of Congress, either individually or collectively, create a sufficient predicate for standing. ${ }^{85}$ Second, the political question doctrine may well have precluded judicial review; indeed, a plurality of the Court had relied on this doctrine to dispose of the last foreign affairs dispute directly between Congress and the executive branch that was brought before the Court. ${ }^{86}$ Finally, because the appropriation, like almost all appropriations, was for a limited period only, the dispute was likely to have become moot before it was ever definitely adjudicated. In short, the Court would have had multiple opportunities to bow out of a foreign policy issue where the institutional costs of getting involved would likely have been high, given the importance of the issue to executive branch interests. It is therefore not surprising that, while the House of Representatives' lawyer bitterly complained about the President's refusal to enforce the law, ${ }^{87}$ members of Congress took no further action.

The president's assertion of constitutional review in this area is exemplified by OLC's opinion supporting the President's action. ${ }^{88}$ Dated three days prior to the President's statement, the opinion underscores that the President was engaged in an act of conscious constitutional review. ${ }^{89}$ The opinion resembles a judicial opinion in its length and elaboration, proceeding in a deliberate manner with copious citation to precedent to articulate three propositions of law: (1) section 102(c) of the Foreign Relations Act was unconstitutional $;^{90}$ (2) the provision was severable from the rest of the act so the president could spend the authorized funds on the negotiations at the Conference on Cooperation and

84. Indeed, by refusing to enforce the law, the President reinforced the accommodation by sending a message to the judiciary that this area of the law is so important to him that he will engage in constitutional review himself and that any intervention risks executive reprisal. See infra notes $100-02$ and accompanying text.

85. For a discussion of reasons that the Supreme Court may be unlikely to grant standing to members of Congress to vindicate their rights of governance, see infra notes 131-33 and accompanying text.

86. Goldwater v. Carter, 444 U.S. 996 (1979).

87. See Marica Coyle \& Fred Strasser, Executive Prerogative, NAT'L L.J., Mar. 5, 1990, at 41. ("For a President to refuse to follow a duly enacted statute with a claim that it's unconstitutional is nothing more than a thin veneer for presidential lawlessness." (quoting Steven Ross, counsel to the House of Representatives)).

88. Memorandum to C. Boyden Gray, Counsel to the President, from William P. Barr, Assistant Attorney General, Office of Legal Counsel, re: Issues raised by Section 102 (c)(2) of H.R. 3792,14 Op. Off. Legal Counsel 38 (1990).

89. I have already discussed the reasons that the President's decision, like the decision of a judge, would likely be final and not reviewed by a court. See supra notes 68-70 and accompanying text.

90. 14 Op. Off. Legal Counsel, supra note 88 , at 38-46. 
Security in Europe without complying with the provision; ${ }^{11}$ and (3) the president had the constitutional authority to refuse to enforce laws that violate the separation of powers. ${ }^{92}$ To support its first proposition, the opinion not only cites judicial precedent, such as United States v. Curtiss-Wright Corp. ${ }^{93}$ but similar interpretations of the Constitution by other presidents, including President Carter's refusal to allow Congress to constrain his choice of representation at U.S. missions abroad, ${ }^{44}$ demonstrating the bipartisan nature of the executive's interest.

The opinion's second proposition rejects absolutely the notion that Congress may use its "power of the purse" to condition the receipt of funds in a manner that would interfere with the president's constitutionally granted prerogatives. ${ }^{95}$ The authority cited for this proposition is another OLC opinion which applies the unconstitutional conditions doctrine to the separation of powers. ${ }^{96}$ Because the doctrine is ordinarily applied by the judiciary to prevent Congress from conditioning the receipt of government funds on the waiver of constitutional rights of individuals, its invocation reminds the judiciary of the importance of retaining this boundary to its own interest in remaining the guardian of individual rights. ${ }^{97}$

The opinion's third proposition, that the president can refuse to enforce laws that violate the separation of powers, is also best understood against the background of the separation of powers as an implicit set of bargains. The textual support for the refusal to enforce, deriving as it does from the president's

91. Id. at $46-48$.

92. Id. at 49-56.

93. 299 U.S. 304, 319-20 (1936) cited in 14 Op. Off. Legal Counsel, supra note 88, at 45-46. CurtissWright quotes favorably John Marshall's statement when he was a congressman that the president is the "sole organ of the nation in its external relations, and its sole representative with foreign nations." Id. at 319-20 (quoting 10 ANNALS OF CONG. 613 (1800)). The case also emphasizes the need for secrecy in negotiations. Id. at 320-21. The actual holding of Curtiss-Wright is fairly narrow: broad delegations by Congress to the executive branch will be upheld when they delegate power that relates to foreign affairs where the president himself has substantial authority. The continuing prominence of the case, however, is due in no small part to the executive's emphasis in its own legal opinions of the passages that discuss the president's inherent authority apart from any delegation. Thus, because of the president's initiative of legal interpretation in the area of foreign affairs, his constitutional lawyers are able to amplify favorable Supreme Court precedent.

94. President Carter's Statement on Signing H.R. 3363 into Law, 15 PUB. PAPERS 1434 (Aug. 15, 1979) ("[D]ecisions associated with the appointment of Ambassadors are acknowledged to be a constitutional prerogative of the President.").

95. 14 Op. Off. Legal Counsel, supra note 88, at $42-43$ n.3.

96. Id. (citing Memorandum to Dick Thornburgh, Attorney General from William Barr, Assistant Attorney General, Re: Constitutionality of the Proposed Limitation on the Use of the CIA Reserve for Contingencies, 13 Op. Off. Legal Counsel 311, 314 (1989) ("Interpreting the appropriation power in this manner would in effect transfer to Congress all the powers of the branches of government.")).

97. See also William P. Barr, The Appropriations Power and the Necessary and Proper Clause, 1990 WASH. U. L.Q. 626, 627 (demonstrating that if Congress is allowed a freestanding power to allocate and control all public resources, it can place conditions on the exercise of jurisdiction by the courts).

Because OLC opinions and executive branch statements about the separation of powers are less visible to the public one would expect that they would offer a more realpolitik analysis of separation of powers issues than the judiciary. For a discussion of the reasons that the branches may be cautious about overtly analyzing separation of powers issues under a rational choice or bargaining model, see supra note 48. 
oath $^{98}$ and his authority to "take Care that the Laws be faithfully executed,"99 does not distinguish between refusing to enforce laws that violate the separation of powers and those that violate other provisions of the Constitution. However, the distinction can be easily understood in terms of the comparative interests of the branches. The executive has the most interest in exercising this power with respect to separation of powers provisions, because these provisions most directly affect its interests. ${ }^{100}$ On the other hand, the judiciary would lose a measure of its most prized prerogative, the protection of individual constitutional rights, if the executive were to refuse to enforce provisions that violate individual rights as freely as it refuses to enforce provisions that violate the separation of powers. ${ }^{101}$ Thus, the effective boundary line between the president's use of his power to refuse to enforce a law and the judiciary's invocation of judicial review is largely set by the balance of interest between these branches rather than the constitutional text. ${ }^{102}$ Indeed, this boundary functions as one of the most fundamental structures of accommodation in the bargaining game, because it divides up the initiative in policing constitutional boundaries between the executive and judiciary.

The executive's decision to elaborate on its refusal to enforce a law and then publish its elaboration also serves several purposes within the bargaining model. The opinion bolsters the legitimacy of the executive's position, particularly because it is one of the few official legal analyses of the issue of the rights of governance over diplomatic representation, given the paucity of judicial precedent. ${ }^{103}$ Moreover, it creates a commitment to refuse similar congressional encroachments in the future. As Schelling has pointed out: "To be

98. U.S. CONST. art. II, $\S 1, \mathrm{cl} .8$ (requiring the president to "preserve, protect and defend the Constitution of the United States"). For a discussion of the significance of the president's oath, see John O. McGinnis, Principle Versus Politics: The Solicitor General's Office in Constitutional and Bureaucratic Theory, 44 STAN. L. REV. 799, 804 \& n.31 (1992).

99. U.S. CONST. art. II, \$3.

100. See supra notes 58-62 and accompanying text.

101. The president has refused to enforce provisions that violate other important executive prerogatives. See, e.g., Letter from Attorney General Smith to Peter Rodino (Feb. 22, 1985) reprinted in, Constitutionality of GAO's Bid Protest Function: Hearings Before the Subcomm. on Legislation and National Security of the House Comm. on Government Operations, 99th Cong., 1st Sess. $432-61$ (1985) (defending the refusal to enforce a provision in the Competition in Contracting Act that violated the separation of powers). By contrast, the executive in the modern era has asserted the right to refuse to enforce provisions that violate the Bill of Rights only when the laws are patently unconstitutional, such as where a bill would order the prosecution of members of a particular party. See $4 \mathrm{~A}$ Op. Off. Legal Counsel 55, 60 (1980) (opinion of Attorney General Civiletti). For further discussion of theories to justify the executive branch's refusal to enforce a law, see McGinnis, supra note 43, at 387-89.

102. The justiciability doctrines by which the judiciary stays its hand in war powers and foreign affairs can be seen as the mirror image of the executive's decision not to use its power to refuse to enforce the laws in disputes that do not relate to the separation of powers. For a discussion of the effect of these justiciability doctrines, see infra notes $126-28$ and accompanying text.

103. Precedents are important in the bargaining model because as Schelling suggests, "[p]recedent seems to exercise an influence that greatly exceeds its logical importance or legal force .... [O]ften it seems that there is simply no heart left in the bargaining when it takes place under the shadow of some dramatic and conspicuous precedent." SCHELLING, supra note 25, at 67-68 (footnote omitted). Thus, a failure to transgress the boundaries of the powers of the other branch may actually strengthen the fences that mark the boundaries. 
convincing commitments usually have ... to rest on some rationale."104 Publicizing these commitments may also strengthen one's negotiating position: "If in the past one has successfully maintained [a] principle, . . . and elects to nail his demands to that principle . . . he may persuade his adversary that [he will not give up the principle.]"105 By articulating the principles that the executive will not concede, OLC generates commitments for the future that may strengthen the president's bargaining position vis-a-vis the other branches. ${ }^{106}$

The executive branch's response to this legislation also shows why the executive branch has an advantage over Congress in creating favorable legal precedent. For the reasons just discussed, this legislation presented an excellent opportunity for the president to make good law with negligible risk of congressional or judicial reaction. Why then did Congress give the president this opportunity? The answer almost certainly lies in the relative dispersion of authority in Congress and the consequent lack of any institutional mechanism for long-term planning and enforcement of a legal strategy. ${ }^{107}$ This void permits staffers and individual members of Congress to press for provisions that are not well-designed to advance congressional claims to constitutional powers and, in fact, may offer the president strategic opportunities for reaffirming his own power. ${ }^{108}$ Moreover, because the congressional leadership has difficulty in monitoring potential confrontations, Congress is thrust into positions that its leadership is not willing to spend the political capital to defend. ${ }^{109}$ In contrast, the executive branch with its hierarchical structure, particularly in the area of foreign affairs, is better positioned to develop and enforce a long-term strategy.

104. Id. at 34.

105. Id.

106. The notion that the president may strengthen his bargaining position by public precommitments is not unfamiliar. See, e.g., Daniel E. Ingerbam \& Dennis A. Yao, Presidential Commitment and the Veto, 35 AM. J. POL. SCI. 356, 358 (1991) (arguing that veto power can be enhanced by a public declaration of features that would trigger a veto because this mechanism makes it harder for the president's "future self to accept bills with prescribed features"); Michael B. Rappaport, The President's Veto and Constitution, 87 Nw. U. L. REV. 735,784 (1993) (suggesting that president deter the passage of appropriation bills with substantive riders by pledging that he will veto all such bills).

107. For a discussion of the growth of centralized legal institutions in the Congress, see Geoffrey $P$. Miller, From Compromise to Confrontation: Separation of Powers in the Reagan Era, 57 GEO. WASH. L. REV. 401, 415 (1989). For the reasons indicated in the text, however, the relative dispersion of authority in Congress limits the effectiveness of its centralized coordinating institutions.

108. The members of Congress who addressed the propriety of the provision that prohibited spending any of the authorized money for the Conference on Cooperation and Security in Europe unless representatives from the Commission on Security and Cooperation and in Europe were included in the delegation emphasized that the commission was not a "congressional committee." See 135 CONG. REC. S8025 (daily ed. July 17,1989 ) (statement of Sen. Fowler). The strength of this distinction, given that the Committee was composed almost entirely of members of Congress, would have been questioned by any lawyer with expertise in the separation of powers.

109. Professor Koh suggests Congress would strengthen its position if it created the office of congressional legal adviser. See $\mathrm{KOH}$, supra note 60 , at 169 . Perhaps such a coordinator would be of some assistance, but it would hardly cure the dispersion of power and diffuseness of individual members' interests that is the root cause of Congress's comparative disadvantage in pressing its legal position. Indeed, the Senate and the House already have central legal offices (the Office of the Counsel to the Clerk of the House and the Senate Legal Counsel) to advise them, but they do not prevent incidents like the one described above from occurring. 


\section{B. The Executive's Reaction to the War Powers Resolution}

The War Powers Resolution ${ }^{110}$ appeared to represent a far more systematic challenge to a core interest of the president-his authority to deploy and engage the armed forces to protect national security. The Resolution was enacted at a time when the presidency was at a low ebb, both because it was beset by the watergate scandal and considered responsible for the conduct of the increasingly unpopular Vietnam War. Yet, despite the claims of its sponsors that the War Powers Resolution would fundamentally restructure the relationship between the president and Congress in decisions about the use of force abroad, this legislation has had no lasting effect on the president's authority to commit troops abroad. In fact, it was considered so ineffective by the end of the 1980 s that its repeal or radical amendment was seriously considered. ${ }^{111}$

First, the Resolution challenges the president by suggesting that his authority to take military action is limited:

The constitutional powers of the president as Commander-in-Chief to introduce United States Armed Forces into hostilities, or into situations where imminent involvement in hostilities is clearly indicated by the circumstances, are exercised only pursuant to (1) a declaration of war (2) specific statutory authorization, or (3) a national emergency created by an attack upon the United States, its territories or possessions, or its armed forces. ${ }^{112}$

Section 4(a) of the Resolution mandates that the president submit a report to Congress when United States forces are introduced into any of three situations: $:^{113}$

(1) into hostilities or into situations where imminent involvement in hostilities is clearly indicated by the circumstances;

(2) into the territory, airspace or waters of a foreign nation, while equipped for combat, except for deployments which relate solely to supply, replacement, repair, or training of such forces; or

(3) in numbers which substantially enlarge United States Armed Forces equipped for combat already located in a foreign nation.

In these circumstances the president is required within forty-eight hours to submit a report to Congress which sets forth: ${ }^{114}$

(A) the circumstances necessitating the introduction of United States Armed Forces;

(B) the constitutional and legislative authority under which such introduction took place; and

110. Pub. L. No. 93-148, 87 Stat. 555 (1973) (codified at 50 U.S.C. \$\$ 1541-1548 (1988)).

111. For discussions by adherents of greater congressional authority in the war power area, see $\mathrm{KOH}$, supra note 60, at 123-28, 187-93. See generally John Hart Ely, Suppose Congress Wanted a War Powers Act that Worked, 88 COLUM. L. REV. 1379 (1988).

112. 50 U.S.C. \& 1541 (c) (1988).

113. Id. § 1543(a).

114. Id. 
(C) the estimated scope and duration of the hostilities or involvement.

The report filed under 4(a)(1), detailing the introduction of forces into hostilities or into a situation of imminent hostilities, is the most significant report under the terms of the Resolution, because only a report filed under those circumstances triggers a clock which purports to require the president to "terminate" the use of armed forces by the end of sixty days in the absence of congressional authorization. ${ }^{115}$ This termination provision is central to the War Powers Resolution, because it is the only mechanism in the Resolution for enforcing the constitutional powers that Congress is claiming.

President Nixon vetoed the War Powers Resolution, declaring that it was unconstitutional, ${ }^{116}$ but it was passed over his veto. After some initial uncertainty over how to deal with the Resolution, the executive branch settled on a strategy both to avoid compliance and to signal to the judiciary the strength of the executive's interest in this issue, thus raising the stakes of any decision by the judiciary to enforce compliance. ${ }^{117}$

First, at every opportunity, the president asserts that he is committing forces abroad pursuant to his constitutional authority as commander-in-chief, implicitly countering the premise of the Resolution that the executive branch is restricted in its use of forces to the catalogue specified. ${ }^{118}$ Indeed, the letter the president typically sends to Congress concerning the commitment or use of troops abroad includes the language "consistent with the War Powers Resolution" (rather than some such language as "pursuant to"), which signals that he does not accept the constitutionality of the provision. ${ }^{119}$ Although letters from the president regarding the constitutional basis of any particular commitment of force are terse, in testimony before Congress, representatives of the executive branch have expounded at length on the inadequacies of section 2(c) of the Resolution. For instance, as Legal Adviser to the State Department, Judge Abraham Sofaer stressed that the president clearly had authority to protect U.S. citizens and

115. Id. $\S 1544(\mathrm{~b})$. Section 5(c) of the Resolution allows Congress affirmatively to terminate use of U.S. forces by a two house concurrent resolution. INS v. Chadha, 462 U.S. 919 (1983), invalidated legislative vetoes. See supra note 38 and accompanying text.

116. President Nixon objected to the automatic termination provision now contained in 50 U.S.C. $\S 1544$ (b) as well as to termination by concurrent resolution in 50 U.S.C. $\S 1544$ (c). 9 WEEKLY COMP. PRES. DOC. 1285, 1286 (1973).

117. For a history of the executive branch's "compliance" with the War Powers Resolution until 1984, see Memorandum to the Attorney General from Theodore Olson, Assistant Attorney General, Office of Legal Counsel, Re: The War Powers Resolution, 8 Op. Off. Legal Counsel 336 (preliminary print 1984). For examples of executive's recent treatment of the War Powers Resolution in the course of its military actions, see supra note 2 .

The president's statements are carefully drafted by his leading constitutional lawyers. In the Reagan and Bush Administrations, there was a War Powers Working Group comprised of the Counsel to the President, the Assistant Attorney General for the Office of Legal Counsel, the Legal Adviser of the State Department, and the General Counsel of the Defense Department.

118. For examples of recent presidential assertions of inherent constitutional authority in the War Power context, see infra note 120 and accompanying text.

119. See the letter of President Reagan on Grenada and the letter of President Bush on Panama, supra note 2. 
property overseas without authorization from Congress. ${ }^{120}$ Additionally, the formal opinions of OLC in this area take every opportunity to emphasize this aspect of the president's power. Recently, in connection with the Somalia operation OLC stated:

\begin{abstract}
At the core of this power is the President's authority to take military action to protect American citizens, property, and interests from foreign threats. See, e.g., Presidential Powers Relating to the Situation in Iran, 4A Op. OLC 115, 121 (1979) ("It is well established that the President has the constitutional power as Commander- in-Chief to protect the lives and property of Americans abroad.") Presidential Power to Use the Armed Forces Abroad Without Statutory Authorization, 4a Op. OLC 185, 187 (1980) ("Presidents have repeatedly employed troops abroad in defense of American lives and property."); see also Memorandum of William H. Rehnquist, Assistant Attorney General, Office of Legal Counsel, Re: The President and the War Power: South Vietnam and the Cambodian Sanctuaries, 8 (May 22,1970) (President as Commander in Chief has authority "to commit military forces of the United States to armed conflict ... to protect the lives of American troops in the field"). ${ }^{121}$
\end{abstract}

The interest the executive branch has in emphasizing the justification for military action premised on the president's authority to protect life and property is threefold: First, there is substantial historical precedent for unilateral executive action in this regard, ${ }^{122}$ and historical practice can become the focal point of an accommodation in much the same way that constitutional text can provide a focal point particularly when the text itself is silent or ambiguous on an issue. ${ }^{123}$ Second, given the widespread dispersion of U.S. citizens and property around the world, this justification will be available for a wide variety of actions; it could be invoked in instances as diverse as Grenada, Panama, and the protection of shipping in the Persian Gulf. Third and most importantly, the protection of U.S. lives and property offers a justification that the judiciary would be particularly wary of challenging. If the judiciary intervened, the prospect of specific lives at stake might well offer the executive a rationale for ignoring its order with the resulting incalculable harm to the judiciary's prestige. On the other hand, if the executive were to obey the order and lives were lost as a result, the judiciary's reputation would also be damaged. Thus, in

120. See Statement of Abraham D. Sofaer, supra note 63 ("Specifically, section 2(c) omits, for example, the protection or rescue from attack, including terrorist attacks, of U.S. nationals in difficulty abroad; the protection of ships and aircraft of U.S. registry from unlawful attack; responses to attacks on allied countries with which we may be participating in collective military security arrangements or activities, even where such attacks may threaten the security of the United States or its armed forces; and responses to unlawful attacks on friendly vessels or aircraft in their vicinity.").

121. Memorandum to the Attorney General from Timothy E. Flanigan, re: Authority of the President to Use Military Forces for the Protection of Relief Efforts in Somalia, 16 Op. Off. Legal Counsel 8, 10 (1992).

122. Much historical precedent is collected in Memorandum to the Attorney General from Charles J. Cooper, Assistant Attorney General, Office of Legal Counsel, re: The President's Compliance with the Timely Notification Requirement of Section 501(B) of the National Security Act, 10 Op. Off. Legal Counsel 159, 166-68 (1986).

123. For a discussion of these reasons, see supra note 34-36 and accompanying text. 
emphasizing its obligation to protect U.S. lives and property, the executive branch not only asserts its authority but emphasizes the risks of judicial intervention to enforce the sixty-day cut-off.

The next element in the executive's strategy is to prevent the sixty-day clock from running whenever there is any doubt about whether the clock has been triggered by events described in section 4(a)(1) of the Resolution. ${ }^{124}$ After a military incident, the president generally offers information about the incident to Congress. ${ }^{125}$ He does not, however, invoke a particular section of the War Powers Act. ${ }^{126}$ The result is to maximize the ambiguity concerning whether the president has triggered the sixty-day clock by a report under section $4(a)(1)$.

This strategy has several advantages from the president's point of view, because it effectively leaves Congress with three options, none of which offers a generally promising prospect of enforcing the Resolution. First, Congress can do nothing. The president, however, remains at liberty to assert in the future that this was not a report under section 4(a)(1) and he may well have used the interim time to make it more politically difficult for Congress to resist his commitment of troops.

Second, Congress can pass a resolution setting a sixty-day termination deadline for the president's use of force. This strategy, however, seems to underline the worthlessness of the War Powers Resolution from Congress's point of view, since Congress could enact a specific statute setting a deadline even if the War Powers Resolution did not exist. Indeed, the War Powers Resolution and the president's response may have the perverse effect of making it harder for Congress to set a specific deadline, because some members will take advantage of the ambiguity of the president's message to suggest that there is no need to start the clock because the president has started it himself.

Third, members of Congress can go to court and attempt to obtain a judicial declaration that the clock has started, where there is, in fact, a risk of imminent involvement in hostilities. The context for judicial intervention on behalf of Congress, however, is decidedly unfavorable, because Congress itself has failed to act legislatively to start the clock in the specific situation at hand. In contrast, the executive has already taken action with real world consequences, thus indicating its seriousness. Under these circumstances, it is hardly surprising that, in an accommodation model, the courts often invoke some sort of justiciability

124. Only a report pursuant to section 4(a)(1) triggers the sixty-day clock. The events satisfying the section are the introduction of U.S. forces into hostilities or the prospect of imminent hostilities. See supra notes 113-15 and accompanying text.

125. For examples of such letters, see supra note 2.

126. Classic examples of this strategy are President Reagan's letters concerning certain skirmishes with Iranian forces in the Persian Gulf in 1987. See Letter to the Speaker of the House and the President Pro Tempore of the Senate, PUB. PAPERS 1074-75 (Sept. 24, 1987); Letter to the Speaker of the House and the President Pro Tempore of the Senate, PuB. PAPERS 1164-65 (Oct. 10, 1987). Some Congressman sued to have these letters declared section $4(a)(1)$ reports, but the executive argued that this was a nonjusticiable issue and prevailed. See infra notes 127-28 and accompanying text. 
doctrine that leaves the initiative to the executive. ${ }^{127}$ For instance, the U.S. District Court for the District of Columbia routinely dismisses, on both political question and equitable discretion grounds, suits seeking a declaratory judgment that section 4(a)(1) has been triggered. ${ }^{128}$ In doing so, it sometimes openly acknowledges that its decision is motivated by the judiciary's comparative disadvantage (as compared to the other branches) in determining whether "hostilities" have commenced or are "imminent". ${ }^{129}$

Thus, although the executive branch has adopted a more subtle strategy of noncompliance with respect to the War Powers Resolution than in response to section 102(c) of the Foreign Relations Act, the effect is much the same: the statute is effectively nullified. In both instances, the president defies Congress's attempt to place a condition on the exercise of a core power (presidential power to choose negotiators or commit troops). By doing so, the president sends a signal to the Court of the importance attached to this right of governance. The model of separation of powers offered here suggests that the Court would weigh that signal heavily, particularly when Congress does not take concrete steps to confront the president.

The model also suggests that many of the reforms proposed for the War Powers Resolution will be ineffective because they cannot reorder the institutional interests that militated against the Resolution's efficacy in the first place. For instance, Dean Ely's proposal to grant one or more members of Congress standing to bring suit to start the sixty-day clock would not likely change the practices under the Resolution. ${ }^{130}$ Despite this reform, the bargaining model predicts that the executive branch would act in the same manner as before, attempting both to raise the stakes by asserting its own prerogatives and providing Congress with information but no declaration that would unambiguously start the clock. Although members of Congress could

127. For the reasons that the judiciary will tend to allocate a right to the entity that values it most, see supra note 22 and accompanying text.

The War Powers Resolution is not in itself very persuasive evidence that Congress cares greatly about the exercise of rights of governance in this area, because its passage is consistent with Congress's interest in creating another mechanism for criticizing rather than directing the executive. The executive's failure to comply will offer another procedural basis for criticizing it in the event the commitment of troops is not successful.

128. See, e.g., Lowery v. Reagan, 676 F. Supp. 333 (D.D.C. 1987) (dismissing war powers suit involving U.S. reflagging and military escort operation in the Persian Gulf); Crockett v. Reagan, 558 F. Supp. 893 (D.D.C. 1982), aff'd, 720 F.2d 1355 (D.C. Cir. 1983), cert. denied, 467 U.S. 1251 (1984) (dismissing war powers suit involving military aid to El Salvador).

129. The district courts sometimes indicate that they might adjudicate the dispute if Congress would take more concrete action. Lowery, 676 F. Supp. at 341; Crockett, 558 F. Supp. at 900-01. As discussed previously, there is reason to believe that because of its largely structural docket the District of Columbia Circuit will tend to impose less strict justiciability doctrines than the Supreme Court. See supra note 68 and accompanying text. Moreover, this kind of dicta can be understood within the rational choice model as in the interest of the judiciary as a whole. It avoids unnecessarily irritating Congress which can take solace in the fact that it might prevail in the future. It also gives the judiciary continuing leverage in the bargaining game. If evidence mounts that Congress values the war powers right more than the executive, the judiciary retains the discretion to allocate additional rights of governance in the war powers area to Congress.

130. Ely, supra note 111, at 1412 . 
attempt to sue the executive, the courts would have to entertain the suit on its merits for the proposal to be successful. Indeed, the Supreme Court has never recognized congressional standing, ${ }^{131}$ and its hesitancy about doing so is readily understandable within the separations of powers model offered here. Giving standing to members of Congress not only would risk the ire of the executive, but would also provide Congress with a mechanism for increasing the Court's docket of separation of powers disputes, a class of disputes the Court may well be less interested in adjudicating than those involving the Bill of Rights. ${ }^{132}$ Moreover, the congressional standing would give Congress substantial control over the timing of court decisions, thus detracting from the Court's autonomy. ${ }^{133}$

Even aside from indicating that the Court may be disinclined to permit congressional standing, the model of separation of powers offered here suggests that the judiciary may paradoxically be more likely to invoke a justiciability doctrine and refuse to hear the merits of a suit based on a congressional standing provision. By enacting the standing provision, Congress would signal its weakness and relative unwillingness to spend its own political capital on obtaining more rights of governance in this area through direct confrontation with the executive in the hope that the Court would do its work for it. ${ }^{134}$ Thus, if the original accommodation was created by the Court's understanding that war powers are more important to the executive than to Congress, the introduction

131. Dean Ely notes in passing that the Supreme Court has been loath to recognize standing, but fails even to address the powerful normative arguments which suggest that the original conception of Article III leaves no room for congressional standing. Id. at 1412 \& n.97. Because this is resolutely an explanatory rather than normative essay, I will leave the merits of those arguments aside, while noting that they are available to a court that wants to avoid entertaining the suit by invoking a justiciability doctrine. For a thorough argument that Article III does not countenance congressional standing, see Barnes v. Kline, 759 F.2d 21, 41 (D.C. Cir. 1985) (Bork, J., dissenting) (contending that neither the houses of Congress nor individual members have standing to challenge the congressional veto).

132. For reasons discussed above, see supra notes 65-67 and accompanying text, it seems unlikely that separation of powers disputes advance the Court's interests as much as disputes concerning the Bill of Rights.

The Court of Appeals for the District of Columbia has been more willing to entertain congressional standing. See, e.g, Barnes v. Kline, 759 F.2d 21 (D.C. Cir. 1985). For reasons discussed above, see supra note 67 and accompanying text, the incentives for that circuit may be very different from the Supreme Court because almost its entire docket consists of structural issues and it has no Bill of Rights issues arising from the states.

133. I recognize that even if the Court sustained a doctrine of congressional standing, other justiciability doctrines may be available to avoid adjudicating the disputes. Nevertheless, acknowledging that members of Congress had the right to adjudicate their prerogatives in court would create expectations in Congress and the public that the Supreme Court is available to resolve such momentous interbranch disputes as a matter of course and would focus tremendous attention on such cases, thereby making it harder for the Court quietly to deflect adjudication.

134. Professor Koh has made a similar proposal on standing and also suggested that Congress pass a resolution declaring that the political question doctrine should not be applied to render war power disputes nonjusticiable. See Harold Hongu Koh, Why the Executive (Almost) Always Wins in Foreign Affairs Lessons of the Iran-Contra Affair, 97 YALE L.J. 1255, 1335-36 (1988) (Congress should enact a resolution that violations of national security provisions, such as the War Powers Resolution, do not constitute nonjusticiable questions.). Once again, however, exhortations backed by no indication of willingness to spend political capital may well backfire for the same reason as the creation of a provision providing standing to members of Congress. 
of a standing provision may reinforce rather than disturb the Court's calculus. ${ }^{135}$

The model also casts doubt on the wisdom of the proposed tactics of some opponents of the War Powers Resolution. Professor Rostow has suggested the president should have attempted to bring a constitutional challenge to the War Powers Resolution, and has lamented the failure of recent presidents to do so. ${ }^{136}$ Under the bargaining model, however, it seems clear that ignoring the War Powers Resolution and casting doubt on its constitutionality by presidential declaration is a more forceful way of showing the president's interest in this core power than is attempting to obtain judicial resolution. As OLC itself recognized in a similar context, ${ }^{137}$ to invite the judiciary's participation would be damaging, for it would suggest that the president was willing to share with the judiciary the decision on the contours of war powers. Thus, the executive's invocation of the courts would make the judiciary less certain that the war powers is so important to the executive that it should allocate the initiative of constitutional interpretation in the area to the executive. ${ }^{138}$

Professor Carter has made one of the more plausible suggestions for change in the area by proposing that the president's commitments of troops be policed by a cut-off of appropriations for the particular commitment at issue, rather than

135. The most unrealistic reform has been proposed by Sidak, supra note 9, at 113, who argues that the Court should declare offensive military actions unconstitutional in the absence of a formal declaration of war even when Congress has expressly authorized the use of force. For instance, Sidak suggests that the courts should have held that the Gulf war was unconstitutional, because an authorization for the use of force lacked legal significance. Id. at 33. First, Sidak's contention that a formal declaration would have been less ambiguous than a use of force resolution and would have better promoted political accountability seems open to doubt. The public is not schooled in these distinctions, and the news media treated the resolution on the use of force as deciding the question of whether to use the military to oust Iraq from Kuwait. Leaving this aside, however, a model of rational choice (constructed on premises akin to Sidak's own model) is not consistent with the belief that the judiciary would ever declare illegal a military action concurred in by both the Congress and the president, since the risks of such action are too great and the benefits nonexistent for the judiciary. Nor would the risks be ameliorated if the Court, as Sidak suggests, were not to enjoin the use of force, but only declare that its use is unconstitutional. Id. at 113-18. If the other branches were to heed the declaratory judgment, the judiciary would still be held liable for the consequences of the United States's failure to act. If Congress and the president were to ignore the judiciary, they would have set a precedent of ignoring a Supreme Court decision, dealing a very damaging blow to the Court's prestige.

Perhaps Sidak would respond that he is presenting a normative argument for what the judiciary should do rather an explanation of what it does. But given the premises of his own model, his normative exhortations to the judiciary to act in a manner that represents a substantial threat to the judiciary's own interests are so unrealistic as to be of limited utility.

136. See Eugene V. Rostow, President, Prime Minister or Constitutional Monarch, 83 AM. J. INT. L. 740,749 (1989) (arguing for "vigorous judicial intervention" to restore the constitutional balance between Congress and the president in the war powers arena).

137. See Memorandum for the Acting Attorney General, Office of Legislative and Intergovernmental Affairs from Charles J. Cooper, Acting Assistant Attorney General, Office of Legal Counsel, 9 Op. Off. Legal Counsel 102, 110 n.7 (1985) (arguing that the president should not initiate executive privilege claims in court, because by doing so he will suggest that he shares the responsibility for deciding such claims with the judiciary).

138. For a discussion of why the judiciary will allocate the power to the branch that values it the most, see supra notes $21-22$ and accompanying text. 
by the general and prospective cut-off in the War Powers Resolution. ${ }^{139}$ The reason Professor Carter's proposed appropriations cut-off would likely be more efficacious than the current provisions of the War Powers Resolution has nothing to do with the Constitution's text, which permits Congress to legislate prospectively and generally as well as specifically and reactively. Nevertheless, the practical utility of his proposal makes perfect sense in the context of the rational choice model offered here. Under this proposal, Congress would affirmatively respond to the president's action by using and risking a power that is central to its operations, the power of the purse. ${ }^{140}$ The rational choice model would predict that, given the concrete indication of the actual importance of this issue to Congress, the Court would be more likely to enforce the cut-off should the president refuse to comply. Consistent with this prediction, Justice Powell's "constitutional impasse" exception to the usual doctrines of nonjusticiability applied to war powers and foreign affairs disputes already suggests that the judiciary will be more ready to intervene when there are definite indications that Congress is willing to spend political capital to check the president. ${ }^{141}$

\section{Bargaining in Foreign Policy Areas Where the Accommodation Reflects Congress's Predominant Interest}

Shortly after coming to office, President Bush faced congressional opposition in continuing to aid the Nicaraguan Contras. His Secretary of State, James Baker, obtained authorization for such aid by reaching an accord with Congress. ${ }^{142}$ Under a side agreement to the accord President Bush promised to obtain the approval of four committees that had jurisdiction in the area before releasing the aid. ${ }^{143}$ Despite the protests of the President's own counsel that this committee approval arrangement violated Chadha's requirements of

139. See Stephen L. Carter, Going to War over the War Powers, WASH. Post, Nov. 18, 1990, at C1, C4 (This is less a reform of the War Powers Act than a recognition that it needs to be supplanted.).

140. In testimony, Judge Sofaer has similarly suggested that an important defect of the War Powers Resolution lies in the automatic nature of the sixty-day clock which allows Congress to terminate the military action by "mere inaction." Statement of Abraham D. Sofaer, supra note 63, at 3. Judge Sofaer, like Professor Carter, appears to distinguish legislation by which Congress actively and concretely confronts the president from the blanket termination provision of the Resolution.

141. In Goldwater v. Carter, 444 U.S. 996 (1979), the Court dismissed a challenge to the President's authority to terminate a treaty with Taiwan. Although a plurality of the Court invoked the political question doctrine to block consideration of the merits, Justice Powell concurred on narrower grounds of ripeness. Id. at 997 (Powell, J., concurring). Powell believed that the court should not decide the case at that time, because neither the House nor the Senate had taken concrete steps to create a "constitutional impasse."

142. The accord was memorialized in Bipartisan Accord on Central America, PuB. PAPERS 307-08 (Mar. 24, 1989). The side agreement, however, was not included in the official documents of the President, probably for fear of giving it greater precedential weight. For the importance of precedent in separation of powers practice, see supra note 102.

143. The facts are exhaustively recounted in Michael J. Glennon, The Good Friday Accords, 83 AM. J. INT. L. 544 (1989). 
bicameralism and presentment for congressional action, ${ }^{144}$ the White House defended the accord's legality and carried out its terms. ${ }^{145}$

The incident displays the separation of powers as a system of bargains but provides a counterpoint to the first two matters discussed, because it shows the executive branch bargaining away the right not to be checked by Congress other than through a bill passed by both Houses and presented to the president. The executive effectively traded this right for something it wanted more, namely, an appropriation for a foreign paramilitary group. The potential for such bargaining was implicit in Chadha itself. Although Chadha did hold that Congress can act legislatively only by complying with "the single, finely wrought and exhaustively considered procedure" outlined in the "[e]xplicit and unambiguous provisions of the Constitution," "146 it also recognized that the branches are not "hermetically sealed." 147 Because they are not hermetically sealed, the branches can make deals outside the legislative framework that closely replicate the effect of the legislative veto. ${ }^{148}$ Even if it believed that these deals violated the Constitution, the Court would have great difficulty preventing them because the deals can be struck tacitly. ${ }^{149}$

Bush's confrontation with Congress also reflects that interests at stake in the distribution of foreign aid are very different from those at stake in the deployment of troops or in the dispatch of envoys for negotiation. When the executive branch commits troops, it generally emphasizes that lives of U.S. citizens are directly at risk. ${ }^{150}$ It can thus raise the stakes and prevent a congressional or court challenge to the executive's authority. The distribution of aid, even military aid, to allies is harder to link to such claims of overriding necessity. If intervention were so imperative to U.S. interests, why did the President not send troops? Moreover, the interests for Congress in controlling the distribution of military aid are substantial. Expenditures on foreign aid, considered less vital to essential national interests, are in more direct competition

144. Bernard Weintraub, Bush \& Congress Sign Policy Accord on Aid to Contras, N.Y. TIMES, Mar. 25,1989 , at page 1, col. 6. C. Boyden Gray complained that agreement was inconsistent with Chadha.

145. Secretary of State Baker disagreed with Gray, saying that "the accord enhanced the President's power to shape foreign policy." Thomas L. Friedman, Baker Says Accord on Contra Aid Enhances Powers of the President, N.Y. TIMES Mar. 27, 1989, at A10 col. 1.

146. INS v. Chadha, 462 U.S. 918,945 (1983).

147. Id. at 951 .

148. The rule in Chadha is a formal one. As Professor Lawson writes, "One of the often overlooked virtues of formalism is that ... [once] you know the rules you can work around them, and quite often achieve your substantive goals without any constitutional monkey business." Gary Lawson, Territorial Governments and the Limits of Formalism, 78 CAL. L. REV. 853, 909 (1990). See also Stephen Breyer, The Legislative Veto After Chadha, 72 GEO. L.J. 785, 793 (1984) (suggesting that even under the framework of Chadha, the effect of the legislative veto could be replicated by requiring that agency regulations be introduced as legislation subject to a "fast-track" approval process requiring an up or down vote within sixty days).

149. As the accommodation model would suggest, when Congress and the president have reached an accord in the foreign policy area, the courts are unlikely to intervene. Indeed, a federal district court dismissed a suit by several members of Congress challenging the constitutionality of this accord on jurisdictional grounds. See Burton v. Baker, 723 F. Supp. 1550, 1552 (D.D.C. 1989).

150. See supra notes $120-22$ and accompanying text. 
with domestic expenditures, which may advance the immediate interests of the legislature. ${ }^{151}$ Accordingly, the regime has been so structured to withhold from the president the kind of unilateral authority in matters of foreign aid that he enjoys in the use of military force.

Finally, this incident reveals a fundamental tension in how different agencies and departments within a single branch approach the bargaining game. Institutions like the Office of the Legal Counsel and the Counsel to the President, that are responsible for the separation of powers that cut across various issues, attempt to publicize the president's commitment to legal principles in order to strengthen his bargaining position with the other branches. The operating divisions of the executive branch, like the State Department, are often more interested in making bargains that will advance the specific part of the president's policy for which they are responsible. Even this partition of labor can be useful to the president, because in the course of bargaining with Congress the operating divisions may argue that greater concessions are necessary in order to overcome the internal opposition of institutions such as OLC.

\section{IV}

\section{CONCLUSION}

Executive branch interpretation in the war powers and foreign affairs area is best understood by viewing the separation of powers as constituted by the rational choices of the branches. Because the branches recognize their interdependence, these choices will result in accommodations that reflect their institutional interests and competencies. The creation of law by executive branch interpretations in the war powers and foreign affairs areas is largely a consequence of an accommodation reflecting not only the interest of the executive, but that of the judiciary. Because accommodations based on power are subject to challenge, much of the content and rhetoric of executive interpretation is best understood as an attempt to legitimize and entrench a favorable accommodation.

More generally, the model of separation of powers offered here casts doubt on whether the separation of powers is capable of fulfilling all the objectives for which it was created. The rational choice model confirms that the strategic dynamics among the three branches do operate to prevent any single entity from enjoying a monopoly of all government power; in this sense, ambition successfully counteracts ambition. ${ }^{152}$ However, so long as the branches have somewhat distinct interests, through accommodation they may effectively exchange and broaden their powers with no guarantee that the order resulting from their accommodations will either reflect the original assignment of powers or

151. Indeed, the Iran-contra scandal was in large part the result of the attempt by the White House to act unilaterally to fund the contra rebels. The strength of the congressional reaction to this attempt to circumvent the appropriation process is a measure of the importance of the appropriation power to Congress.

152. The Federalist No. 51, at 321-22 (James Madison) (Clinton Rossiter ed., 1961) (premise of separation of powers is that "ambition must be made to counteract ambition"). 
systematically advance such overarching objectives as the protection of individual liberty or the limitation of governmental power as a whole. Under a rational choice model, ambition may also cooperate with ambition to transform the Constitution. 
